\title{
HAEMOTHERAPY ANALYSIS: THE TEACHING HOSPITAL OLOMOUC IN 2006
}

\author{
Dana Galuszkova*a , Jan Galuszka ${ }^{\mathrm{b}}$ \\ a Department of Blood Transfusion, Teaching Hospital, Palacky University, Olomouc, Czech Republic \\ ${ }^{b} I^{\text {st }}$ Department of Internal Medicine, Teaching Hospital, Palacky University, Olomouc \\ * e-mail: Dana.Galuszkova@fnol.cz
}

Received: September 12, 2007; Accepted: October 15, 2007

Key words: Haemotherapy/Blood transfusion/Haemovigilance

Aims: Annual evaluation of blood transfusion preparation administration at the University Hospital Olomouc, Czech Republic as a contribution to the European Union haemovigilance system.

Methods: Analysis of blood transfusion preparations released from the Department of Blood Transfusion of the above university hospital and laboratory examination results in receivers of these products for the year 2006. Total hospital consumption and usage in particular medical disciplines in the hospital were assessed.

Results: Red cell concentrates: in total 14347 TU (deleucotised in $20.4 \%$ ). Departments according to usage: surgery, haematooncology, anaesthesiology and surgery intensive care department, and internal medicine department.

Haemoglobin levels were above $100 \mathrm{~g} / \mathrm{L}$ before blood transfusion administration in $24 \%$ of cases.

Platelets: in total $1712 \mathrm{TU}$ ( $100 \%$ manufactured by apheresis, $56 \%$ deleucotised). Platelet counts below $20 \mathrm{x} 10^{9} / \mathrm{L}$ were found in all cases before platelet concentrate administration.

Plasma: in total 5959 TU to 1297 of patients. Departments according to usage: surgery, anaesthesiology and surgery intensive care department, internal medicine and haematooncology. Two hundred and forty nine cases without coagulation parameter monitoring and $333(25.67 \%)$ patients with only $1 \mathrm{TU}$ of administered plasma were found.

Conclusions: The incorrect indications for red cell transfusion preparations were found in eleven patients with haemoglobin levels above $130 \mathrm{~g} / \mathrm{L}$. Underdosing in $25.67 \%$ of plasma administrations signifies dubious indications in these cases. Implementation of the haemovigilance system in practice is now mandatory for the Czech Republic after joining the European Union. Therefore more precise data and analysis of questionable cases with further education of staff in clinical departments are essential for the haemovigilance principle to be applied on a hospital basis in the Czech Republic.

\section{INTRODUCTION}

The Council of Europe's Recommendation on haemovigilance came into operation after admission of the Czech Republic into the European Union ${ }^{1,2}$. Public notice 411/2004 collection is the valid legislative norm clarifying the rules for blood processing in the Czech Republic ${ }^{3}$. This document determines the obligatory supervision of all activities connected to blood transfusion products and the application of blood derivates aimed to enhance the safety of all processes involved. Integral parts of the haemovigilance system are definitions of the criteria for haemotherapy indications and checking their adherence.

Blood donor selection criteria are strict in the processing of blood transfusion components. In all donors the blood count, serological and immunohaematological tests are carried out. The qualitative parameters evaluation according to national standards is continuously provided as well as monitoring of transfusion preparations. The plasma for clinical use is released after a six-month quarantine period and the quality of product storage is ensured $^{4}$. Definitions of haemotherapy indication criteria are integral parts of haemovigilance.
Each hospital that uses transfusion preparations has an obligation to constitute a hospital transfusion committee guaranteeing efficient haemotherapy because criteria for the use of blood components are not currently unified in the Czech Republic. Members of the committee define local hospital guidelines and pursue guideline adherence. Departments of blood transfusion supply the data for haemotherapy analysis.

\section{AIM OF THE STUDY}

The target of the study was evaluation of a spectrum of blood transfusion preparations (BTP) and their usage in the University Hospital Olomouc. The University Hospital Olomouc is directly administered by the Ministry of Health and in 2006 the hospital had bed care capacity 1433 of beds, the number of hospitalised patients 44191 , major surgeries 16579 . Total hospital consumption and usage in particular medicinal disciplines were assessed. 


\section{METHOD}

Analysis of released blood transfusion preparations and evaluation of laboratory examinations according to the date of their administration: haemoglobin levels in the case of erythrocyte BTP administration and platelet count before platelet concentrate administration, international normalized ratio (INR) in the case of plasma administration.

\section{RESULTS}

A total number of 27931 tests for blood compatibility were provided and 21638 transfusion units (TU) of transfusion preparations were administered at the University Hospital Olomouc in 2006. Men recipients received 12439 and women 9199 of TU. The most frequent consumption of BTP was in the age group from 65 to 69 years (2 $870 \mathrm{TU}$ per year), the lowest consumption was in the age category from 10 to 14 years (94 TU per year).

\section{Erythrocyte transfusion preparations}

Total administered amount: $\quad 14347 \mathrm{TU}$,

Red cell buffy coat removed $11425 \mathrm{TU}$,

Deleucotised red cell concentrates 2922 TU (20.4\%)

Erythrocyte use according to departments:

Surgery

Internal medicine

$7594 \mathrm{TU}$

Haematooncology

Anaesthesiology, Surgery intensive

care department

Other departments

$1629 \mathrm{TU}$

$2228 \mathrm{TU}$,

$2063 \mathrm{TU}$ $833 \mathrm{TU}$

Haemoglobin levels before blood transfusion administration:

$\mathrm{Hb}$ below $80 \mathrm{~g} / \mathrm{l}: \quad 36 \%$ of patients

$\mathrm{Hb} 81-90 \mathrm{~g} / \mathrm{l}: \quad 24.5 \%$ of patients

$\mathrm{Hb} 91-100 \mathrm{~g} / 1: \quad 15 \%$ of patients

$\mathrm{Hb}$ above $100 \mathrm{~g} / \mathrm{l}$ : $\quad 24 \%$ of patients

Blood count examinations before red cells transfusion preparations administration were provided in all cases. There were funded red cell transfusions in eleven patients with haemoglobin levels above $130 \mathrm{~g} / \mathrm{L}$.

\section{Platelets}

Platelet concentrates produced by apheresis in $100 \%$ of cases were administered.

Total administered amount 1712 TU (platelet apheresis $746 \mathrm{TU}$, platelet apheresis deleucotised 966 of TU i.e. deleucotised $56 \%$ )

The platelets count were examined before platelet concentrate administration in all cases. There were platelet count values below $20 \times 10^{9} / \mathrm{L}$ in all cases.

\section{Plasma}

Total administered plasma amount 5959 TU to 1297 patients.
Plasma use according to departments:

Surgery

$2962 \mathrm{TU}$

Internal medicine

$610 \mathrm{TU}$

Haematooncology

$158 \mathrm{TU}$

Anaesthesiology, Surgery intensive care department

$1954 \mathrm{TU}$

Other departments

$275 \mathrm{TU}$

249 cases without coagulation parameter monitoring were found.

Recommended dose for administration is $10 \mathrm{ml} / \mathrm{kg}$. In $333(25.67 \%$ ) patients only $1 \mathrm{TU}$ of administered plasma, i.e. insufficient dose were found.

Index plasma/erythrocytes (units).

Median in the University Hospital Olomouc $\quad 0.415$

Surgery

0.39

Internal medicine

0.37

Anaesthesiology and Surgery intensive

care department

0.95

Haematooncology

0.07

Median of 13 university hospitals

in the Czech Republic (in 2004)

Median of 65 hospitals in the Czech Republic

(in 2004)

\section{CONCLUSIONS}

The incorrect indications for red cell transfusion preparations were found in eleven patients with haemoglobin levels above $130 \mathrm{~g} / \mathrm{L}$. In $25.67 \%$ of plasma administration there were low dosages (underdosing). This signalizes dubious indication for plasma administration in these cases. Slightly higher plasma/erythrocyte ratios in anaesthesiology and surgery care departments reflects the influence of a few cases with massive plasma consumption.

The quality of hospital haemotherapy is a cross-disciplinary problem. It is possible to influence it in two different ways. On the one hand the adherence to conditions of good clinical practice during transfusion preparation production in blood transfusion departments is essential. On the other hand constant evaluation of data targeting haemotherapy gained from particular clinical departments and feedback of the analysis of results in clinical practice are necessary. Both procedures are conditions for haemovigilance application into practice. The aim of these analyses is to protect non-indicated administration of transfusion preparations.

\section{REFERENCES}

1. Commission directive $2005 / 61 /$ EC of 30 September 2005 implementing Direction 2002/98/EC of the European Parliament and of the Council as regards traceability requirements and notification of serious adverse reactions and events. In: Official Journal of the European Union 1. 10. 2005: L 256/32-40

2. Commission directive 2005/62/EC of 30 September 2005 implementing Direction 2002/98/ES of the European Parliament and of the Council as regards community standards and specifications relating to a quality system for blood establishments. In: Official Journal of the European Union 1. 10. 2005: L 256/41-48 
3. Vyhláška ze dne 21. června 2004, kterou se stanoví správná výrobní praxe, správná distribuční praxe a bližší podmínky povolování výroby a distribuce léčiv, včetně medikovaných krmiv a veterinárních autogenních vakcín, změn vydaných povolení, jakož i bližší podmínky vydávání povolení k činnosti kontrolních laboratoří (vyhláška o výrobě a distribuci léčiv). In: Sbírka zákonů č. 411/2004, strana 7962, částka 133

4. Guide to the preparation, use and quality assurance of blood components, Recommendation No. R 95) 15, 13th edition. Council of Europe Publishing, January 2007 